\title{
Inter-breeding movements of little auks Alle alle reveal a key post-breeding staging area in the Greenland Sea
}

\author{
Anders Mosbech • Kasper L. Johansen • \\ Nikolaj I. Bech • Peter Lyngs • Ann M. A. Harding • \\ Carsten Egevang $\cdot$ Richard A. Phillips $\cdot$ Jerome Fort
}

Received: 6 April 2011 / Revised: 29 June 2011 / Accepted: 30 June 2011 / Published online: 18 August 2011

(C) Springer-Verlag 2011

\begin{abstract}
Seabirds are important components in marine ecosystems. However, knowledge of their ecology and spatial distribution during the non-breeding season is poor. More investigations during this critical period are required urgently, as marine environments are expected to be profoundly affected by climate change and human activities, with both direct and indirect consequences for marine top predators. Here, we studied the distribution of little auks (Alle alle), one of the most abundant seabird species worldwide. We found that after the breeding season, birds from East Greenland quickly travelled north-east to stay for several weeks within a restricted area in the Greenland Sea. Activity patterns indicated that flying behaviour was much reduced during this period, suggesting that this is
\end{abstract}

A. Mosbech $(\varangle) \cdot$ K. L. Johansen · N. I. Bech · P. Lyngs · J. Fort Department of Bioscience, Aarhus University, Frederiksborgvej 399, 4000 Roskilde, Denmark e-mail: amo@dmu.dk

URL: http://www.dmu.dk

A. M. A. Harding

Environmental Science Department, Alaska Pacific University, 4101 University Drive, Anchorage, AK 99508, USA

C. Egevang

Department of Mammals and Birds, Greenland Institute

of Natural Resources, Kivioq 2, 3900 Nuuk, Greenland

R. A. Phillips

British Antarctic Survey, Natural Environment Research Council, High Cross, Madingley Road, Cambridge CB3 OET, UK

J. Fort

Centre d'Ecologie Fonctionnelle et Evolutive, UMR 5175 du

CNRS, 1919 route de Mende, 34293 Montpellier cedex 5, France the primary moulting region for little auks. Birds then performed a southerly migration to overwinter off Newfoundland. These preliminary results provide important information for the conservation of this species and emphasise the need for further studies at a larger spatial scale.

Keywords Alle alle $\cdot$ Stopover site $\cdot$ Moult $\cdot$ Geolocator . Migration $\cdot$ Inter-breeding distribution

\section{Introduction}

The little auk (Alle alle) is a small seabird $(\sim 150 \mathrm{~g})$, breeds in the high Arctic and feeds almost exclusively on zooplankton (Stempniewicz 2001). Given their restricted diet and high energy demand (Harding et al. 2009), they are particularly sensitive to local variability in prey abundance (Karnovsky et al. 2010). The little auk is also the most numerous seabirds in the North Atlantic (Barrett et al. 2006) and therefore a major component in marine ecosystems (Mehlum and Gabrielsen 1995; Karnovsky and Hunt 2002). Despite its importance, little is known about the distribution and ecology of this species outside the breeding season (Fort et al. 2010a, b). However, this is critical information given evidence that climate change will be particularly pronounced in the high Arctic (IPCC 2007), and impacts on the diversity and distribution of zooplankton communities are likely to be major (Beaugrand et al. 2010). In addition, reduction in sea ice extent and duration will allow oil and gas extraction in offshore areas around both Greenland (Boertmann et al. 2009a, b) and Norway, potentially putting further pressure on little auk populations.

The main objective of this study was therefore to locate important at-sea areas of little auks during the non-breeding period to help understand and predict population responses 
to changing climate and the potential impacts of oil extraction activities. Geolocators were used to study the migration of little auks at a major colony on the east coast of Greenland, where more than 3.5 million pairs are estimated to be breeding (Kampp et al. 1987). In addition, we describe a new analytical approach to optimise the use of geolocator data.

\section{Materials and methods}

\section{Deployment and recapture}

Geolocators (Global Location Sensor or GLS loggers) are small archival tags that record changes in light intensity over time and are used to estimate the spatial location of wide-ranging animals over long periods (Egevang et al. 2010). In July 2007 and 2008, we caught 52 little auks (2007 $n=30,2008 n=22)$ in nest crevices in the Kap Høegh colony (70 deg 44' N, 21 deg 35' W; Fig. 2) and fitted them with a geolocator (Mk13, British Antarctic Survey; mass $=1.4 \mathrm{~g}, \sim 1 \%$ of adult body mass). Geolocators were attached to tarsus bands using cable ties. In 2007, we observed successful fledging in 23 of the 30 nests where one of the mates was fitted with a logger. In total, 11 birds with loggers were observed back at the colony in the year following deployment (2008 $n=7$ (23\%), $2009 n=4(18 \%))$. Ten of these birds were recaptured (2008 $n=6,2009 n=4)$, loggers retrieved and a small amount of blood collected for subsequent molecular sexing (Fridolfsson and Ellegren 1999). Data were extracted from only five of these loggers because of water ingress resulting from mechanical damage or temperature extremes. Data from a sample of control birds captured at other nests at Kap Høegh indicated a return rate of $61 \%$ to the nest used the previous year (Jerome Fort unpublished; $n=18$ ). The low recapture rate observed in birds equipped with a GLS logger could be due to lower survival, higher frequency of non-breeding or more changes in nest-site location compared with controls. Little auks recaptured with a logger had a similar body mass to a control group of non-equipped birds $(n=64$, Mann-Whitney test, $U=132.5, P=0.53$; all masses measured during late incubation), suggesting that there was no effect of the logger on body condition in these individuals. Moreover, all recaptured birds were breeding in the year of recapture. In addition, the recapture rate after 1 year following deployments of loggers of a similar size and weight in 2009 was 53\% (Fort unpublished). Therefore, the most likely explanation for the poor recapture rate in our study was that we selected nest sites on the edge of the colony with easy access, which are likely to be suboptimal, resulting in low nest fidelity.
Analysis of location data

Light-level data were downloaded and decompressed in BASTrack. They were then converted to approximate times of dawn and dusk (transitions) in TransEdit using sunrise and sunset thresholds of 10 . On the basis of calibration data collected prior to the deployment of the tags ( $\operatorname{tag} 8379$ : 19-22 Jun 2008 at 45.5 Deg. N, all other tags: 13-20 Jun 2007 at 55.8 Deg. N) and the threshold of 10, a sun elevation angle of -4.7 degrees was estimated. The transitions generated by TransEdit were converted to geographic coordinates in BirdTracker using the estimated sun elevation angle. Coordinates were calculated for both local noon and midnight, and a movement compensation algorithm was applied. The tags were deployed and recovered at high latitude during periods of almost continuous daylight, and for these periods, geographic coordinates could not be calculated. Thus, location data were only available from late August to early May, corresponding to the non-breeding period (Table 1).

Positions obtained using geolocators are typically associated with mean errors of $185-200 \mathrm{~km}$ (Phillips et al. 2004; Shaffer et al. 2005). As a result, the location data are noisy and the coordinates obtained from the processing described above could not be used directly to determine migration routes and habitat use. For this reason, the raw position data are often smoothed to varying degrees by a moving average calculated over an arbitrarily defined interval of several days (Phillips et al. 2004; Guilford et al. 2009). Instead, we applied a modelling approach, as this in contrast to a simple moving average allows us to formally determine the appropriate degree of smoothing. The longitudes and latitudes recorded by each geolocator were treated as separate response variables in generalised additive models (GAM) using a smooth function of time (decimal days since January 1) as the explanatory variable (Wood 2006). Thin plate regression splines were used as the basis of the smooth term, and following the recommendation of Kim and $\mathrm{Gu}$ (2004), the basis dimension k was raised from a default of 10 to $10 \mathrm{n}^{2 / 9}$ to ensure enough degrees of freedom were available for the smooth term to fit the relationship. The actual effective degrees of freedom of the smooth term, and thereby the appropriate smoothness, was estimated from the data by means of generalised crossvalidation $(\mathrm{GCV})$. As GCV is known to have a tendency to over fit, the penalty on the use of degrees of freedom was increased by setting gamma to 1.4 as suggested by Kim and $\mathrm{Gu}$ (2004). The modelling was performed in $\mathrm{R}$ version 2.9.0 (R Development Core Team 2009) using the library mgcv version 1.5-2 (Woods 2008).

For a period of several weeks around the times of equinox, latitudes are unreliable or impossible to determine because of equal day length around the globe. Further, they 
Table 1 Details of geolocator deployments on little auks at Kap Høegh, east Greenland in 2007 and 2008

\begin{tabular}{|c|c|c|c|c|c|}
\hline Tag id \# & 6319 & 6324 & 6327 & 6329 & 8379 \\
\hline Sex & Male & Male & Male & Female & Female \\
\hline Headbill (mm) & 53.8 & 56.9 & 56.7 & 53.2 & 50.7 \\
\hline Wing $(\mathrm{mm})$ & 125 & 122 & 123 & 122 & 121 \\
\hline Weight (g) & 163 & 176 & 158 & 144 & 139 \\
\hline Date of deployment & $10 \mathrm{Jul} 2007$ & $10 \mathrm{Jul} 2007$ & $10 \mathrm{Jul} 2007$ & $10 \mathrm{Jul} 2007$ & $11 \mathrm{Jul} 2008$ \\
\hline $\begin{array}{l}\text { Approximate date of } \\
\text { departure from colony }\end{array}$ & 25 Jul-01 Aug 2007 & 10 Aug 2007 & 03 Aug-13 Aug 2007 & 09 Aug-11 Aug 2007 & 01 Aug-04 Aug 2008 \\
\hline $\begin{array}{l}\text { Approximate date of } \\
\text { arrival at staging area }\end{array}$ & Before 21 Aug 2007 & Before 20 Aug 2007 & Before 19 Aug 2007 & Before 29 Aug 2007 & Before 21 Aug 2008 \\
\hline $\begin{array}{l}\text { Approximate date of } \\
\text { departure from staging area }\end{array}$ & 11 Oct 2007 & 5 Oct 2007 & 4 Oct 2007 & 29 Sep 2007 & 6 Oct 2008 \\
\hline Date of recapture & $11 \mathrm{Jul} 2008$ & $06 \mathrm{Jul} 2008$ & $06 \mathrm{Jul} 2008$ & $13 \mathrm{Jul} 2008$ & $11 \mathrm{Jul} 2009$ \\
\hline $\begin{array}{r}\text { Date of beginning } \\
\text { of position data }\end{array}$ & 21 Aug 2007 & 20 Aug 2007 & 19 Aug 2007 & 29 Aug 2007 & 21 Aug 2008 \\
\hline Date of end of position data & 06 May 2008 & 03 May 2008 & 09 May 2008 & 05 Feb 2008 & 18 Feb 2009 \\
\hline $\begin{array}{l}\text { Period of latitude filtering } \\
\text { around autumn equinox }\end{array}$ & 15 Sep-03 Oct 2007 & 15 Sep-08 Oct 2007 & 16 Sep-11 Oct 2007 & 14 Sep-10 Oct 2007 & 13 Sep-12 Oct 2008 \\
\hline $\begin{array}{l}\text { Period of latitude filtering } \\
\text { around spring equinox }\end{array}$ & 26 Feb-28 Mar 2008 & 29 Feb-29 Mar 2008 & 26 Feb-28 Mar 2008 & - & - \\
\hline
\end{tabular}

${ }^{a}$ Determined by the light curve (shadow periods during day time) and immersion data (see text)

Fig. 1 Example of GAM models with latitude and longitude as response variables and a smooth function of time as explanatory variable. Black dots indicate data points included in the model, whereas red dots represent data points filtered out around the times of equinox. Predicted values are given by the solid black line, and the dashed lines represent $95 \%$ confidence intervals

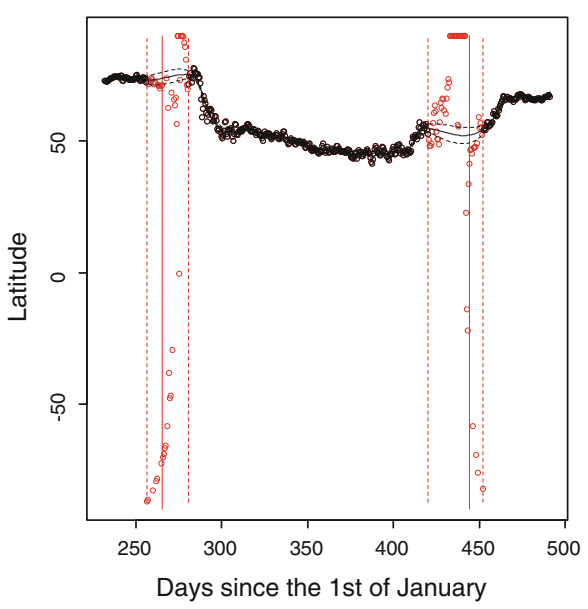

6319

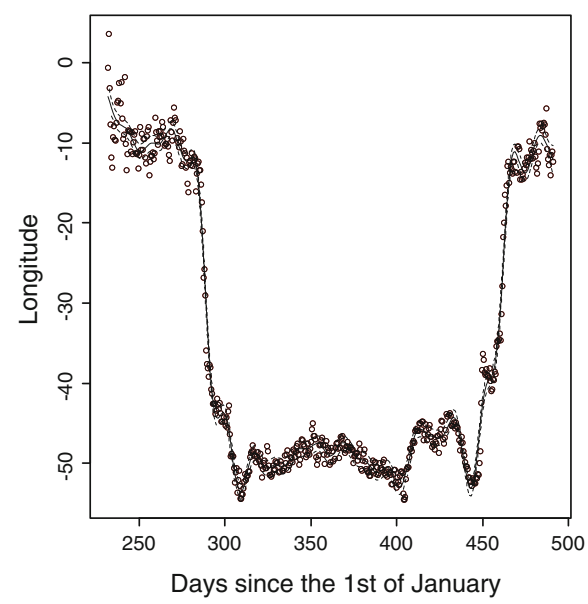

may exhibit a systematic drift. In the northern hemisphere, this drift most severely affects the period immediately after the autumn equinox and the period leading up to the spring equinox. Periods when data were unreliable were therefore excluded from our analyses, based on visual inspection of the latitudes obtained from individual loggers (Table 1, Fig. 1). Longitudes are not influenced by equinox, and so, all values were retained in the dataset used for the GAM models.

Based on the models, daily predictions of longitude and latitude were made for each bird. To avoid extrapolation and associated uncertainties, predictions were limited to the period from first to last location obtained from each logger.
However, predictions were made across equinoxes when latitudes were not available from the original light-level analysis and results in larger standard errors in these periods. Migration routes of individual birds were reconstructed on the basis of the daily positions predicted using the models. The daily predictions of longitude and latitude were also used as a means of defining areas of prolonged stay. In a GIS, each predicted position was represented geographically as an ellipse with the centre defined by the predicted longitude and latitude. The semi-major axis of the ellipse was defined as 1.96 times the standard error of the prediction of longitude and the semi-minor axis as 1.96 times the standard error of the prediction of latitude. These 

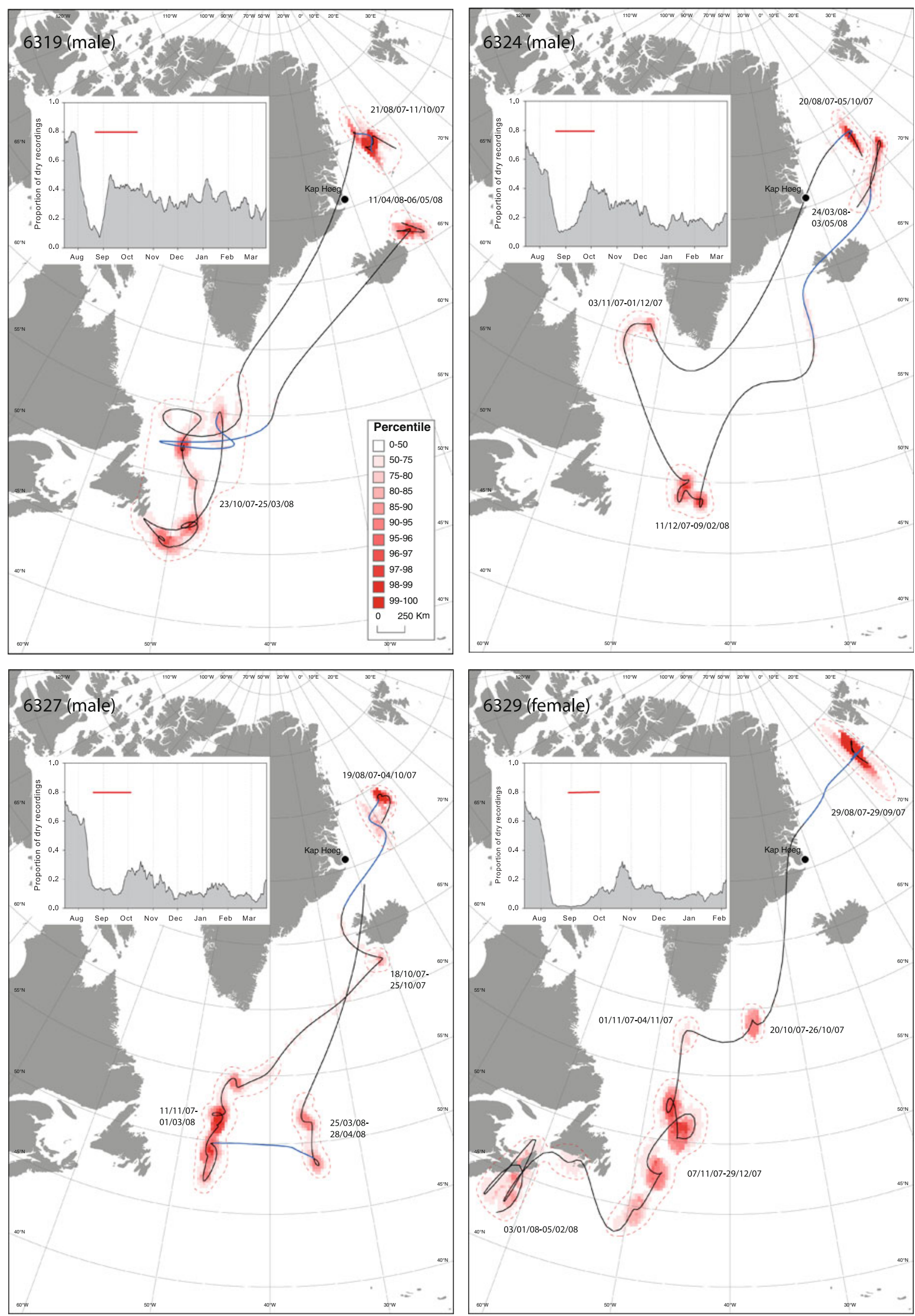

Fig. 2 


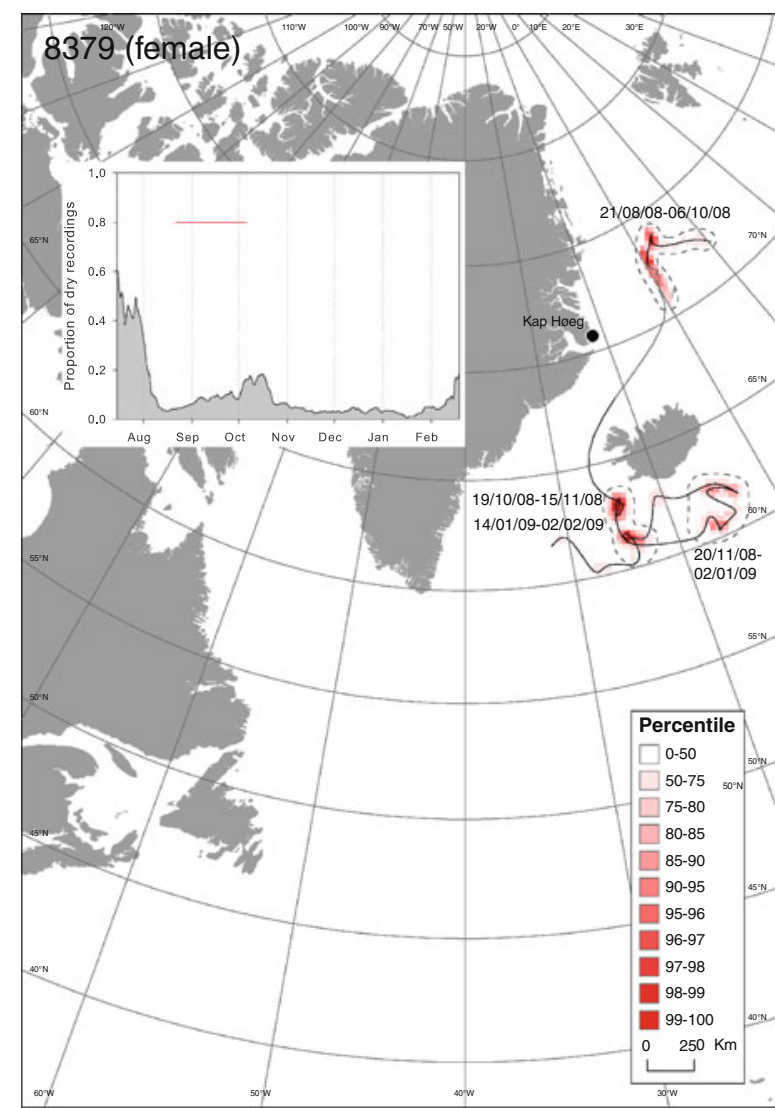

4 Fig. 2 Migration routes and areas of prolonged stay for the five little auks tagged in 2007 and 2008 and recaptured in 2008 and 2009, respectively (see 'Methods' for more details). The tag id number and the sex of the birds are shown on the maps, and dates are supplied for areas in which the birds stayed for longer periods. The blue sections of the path indicate the time periods for which the original latitudes were filtered out due to equinox problems. The daily proportion of dry recordings from the salt water immersion sensor is shown as a graph in each panel (see 'Methods'). The straight red lines in these graphs highlight the period during which each individual occupied the northern postbreeding staging area

error ellipses thus geographically represent $95 \%$ confidence intervals of the predicted positions. A grid of $25 \times 25 \mathrm{~km}$ cells was constructed, and for each bird, the number of overlapping error ellipses within each cell was counted. Since predicted positions of poor precision generate large error ellipses that overlap many cells, each ellipse was weighted so that the $25 \times 25 \mathrm{~km}$ cells, which make up the entire ellipse, sum to 1 . In this way, a relative measure of duration of stay within each cell is obtained, taking into account the uncertainty associated with the predicted positions. As the cell values are not directly comparable from one bird to another, mapping and comparison are based on percentiles, highlighting the most extreme values for each individual. To further emphasise areas of prolonged stay, the percentiles are only based on cells that are overlapped by more than 1 ellipse (Fig. 2).
Ship-based seabird survey data

To substantiate the important at-sea areas identified through analysis of the geolocator data, we compare the areas with a density map of little auks in the Greenland Sea (Fig. 3). This density map was produced on the basis of 6 ship-based surveys conducted during the periods 17/8-8/9 1994, 12/8-12/9 1995, 16/7-30/9 2006, 22/8-22/9 2007, 24/7-3/9 2009 and 27/6-16/8 2010 (NERI Seabirds at Sea Database). Methodologically, all surveys were carried out as on-sided line transect surveys following European Seabird at Sea (ESAS) procedures (Tasker et al. 1984; Webb and Durinck 1992). The survey transects were split into $3 \mathrm{~km}$ segments, and for each segment, a density was calculated on the basis of the number of little auks observed, the length of the segment and an effective search width estimated separately for each survey by means of distance sampling methods (Buckland et al. 2001). Survey by survey, the segment densities were interpolated to raster grids (resolution $3 \times 3 \mathrm{~km}$ ) by inverse distance weighting (power 2, radius $15 \mathrm{~km}$ ), and the density shown in Fig. 3 represent the mean value in an overlay analysis of these grids.

Analysis of activity data

The loggers also check for salt water immersion every $3 \mathrm{~s}$ and store the number of positive tests (a value ranging from 0 to 200) at the end of each 10-min period. For each bird, we calculated the daily proportion of dry recordings from the time of deployment to the point in time when the memory allocated to salt water immersion data ran out (in all cases in February or March) and used this as an indicator of changing activity patterns. During the breeding season, little auks spend time in the colony and the end of the breeding season can therefore be identified by a clear decline in the proportion of dry recordings. During the non-breeding season, little auks are exclusively at sea. Here, low proportions of dry recordings reflect much contact with sea water (i.e. diving or resting on the surface), whereas high proportions would suggest more flying activity. However, dry recordings may arise from activities other than flying (birds lifting their legs out of the water, birds sitting on sea ice) and the proportion of dry recordings in the non-breeding season is therefore not necessarily equal to the proportion of time spent flying.

\section{Results and discussion}

For the five tracked birds, the median departure time from the colony, post-breeding, was 8 August (range 25 July-13 August). An unexpected result was that after leaving the breeding colony, all birds quickly travelled north-east to a staging (stopover) area in the Greenland Sea between 


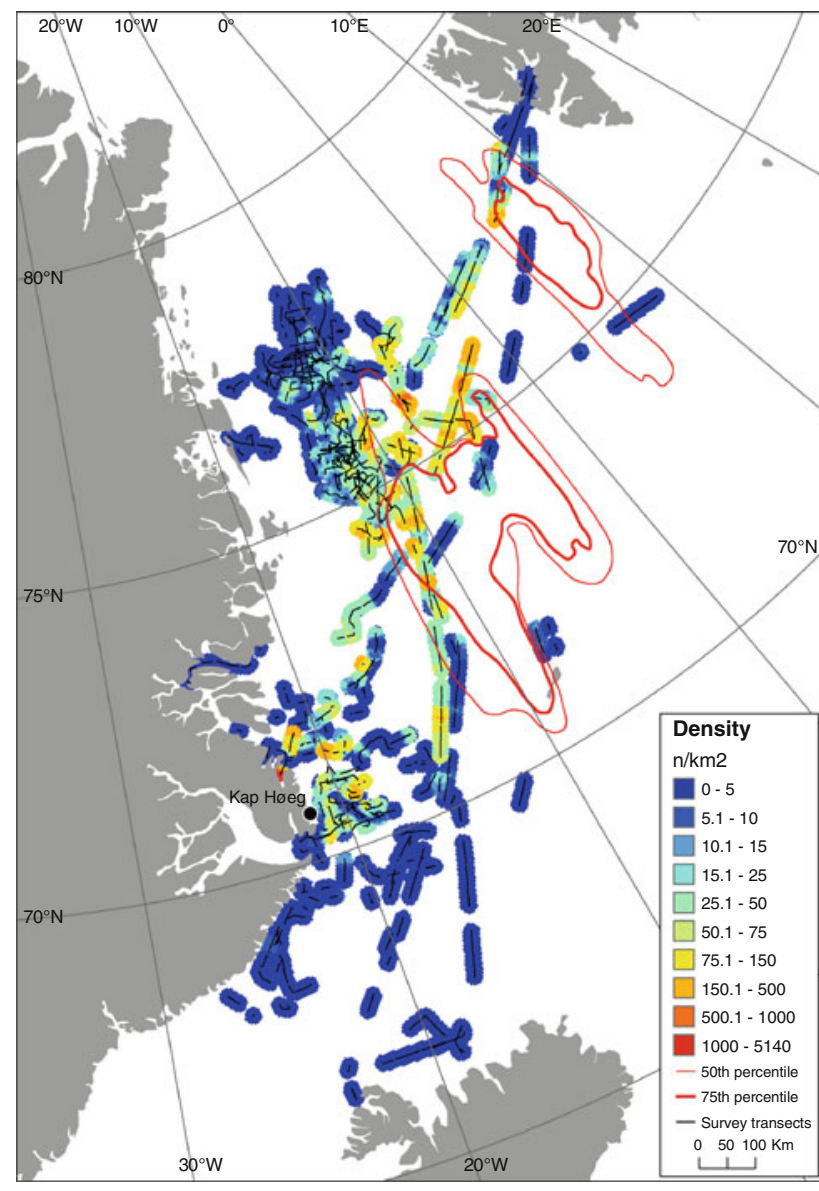

Fig. 3 Density of little auks in the Greenland Sea on the basis of 6 ship-based surveys (see 'Methods' for details). The red lines correspond to the area occupied by the 5 tracked little auks during September (defined by the 50th and 75th percentile of $10 \times 10 \mathrm{~km}$ grid cells scoring the highest values in a weighted overlap of the daily error ellipses (see 'Methods' for more details))

Jan Mayen and Svalbard. Individuals departed from this region at the beginning of October (Fig. 2). During this staging period, logger immersion data showed an important drop of the time spent out of water, followed by a short period of low values (Fig. 2). This period, which lasted in average 22 days $(\min =15$ days, $\max =34$ days), most likely corresponds to the moulting period and the highlighted staging area is therefore likely to be the key moulting site for little auks from the Kap Høegh colony and probably also for the rest of the several million breeding little auks around the Scoreby Sund Polynya in East Greenland. Only little information is available concerning the moult of alcids. Previous investigations performed on captive common guillemots showed that birds were flightless for a period of 4-6 weeks (Birkhead and Taylor 1977). This is in accordance with our observations on little auks that might become flightless for a slightly shorter period than guillemots.
Ship-based seabird surveys performed in the Greenland Sea between 1994 and 2010 confirmed a relatively high density of little auks in this area and far fewer in the region south of Scoresby Sund (including Kap Høegh) during the first months post-breeding (Fig. 3). Within the staging area defined by the 50th percentile (Fig. 3), 97.8\% of the little auks recorded during the ship-based surveys in the months of August and September were observed on the sea surface and only $2.2 \%$ were flying $(n=11,279)$. This supports the theory that the identified post-breeding staging area in the Greenland Sea is indeed a moulting area. The surveys indicated that few other bird species besides little auks use the area in the period in question. Only thick-billed murres, northern fulmars and black-legged kittiwakes were observed with some frequency. In an attempt to understand why the little auks use this particular area for moulting, we have analysed remote sensing data on chlorophyll-a concentration and sea surface temperature from OceanColorWeb (http://oceancolor.gsfc. nasa.gov) and sea ice concentration from Ocean and Sea Ice SAF (http://osisaf.met.no). Neither sea surface temperature nor sea ice concentration shows any evident correlation with the moulting area. Chlorophyll-a concentration measured during the spring bloom in June 2007 revealed high primary productivity in the moulting area, but whether this results in profitable foraging condition for little auks when they arrive in the autumn is unknown.

In early October, all birds performed a southerly migration of up to 2,000 km to their main wintering site. Although most went directly from the staging area to their wintering ground, one bird first went to south-west Greenland where it remained for a month before departing for its main wintering area. The speed of movement of the five birds from the presumed moulting area to the wintering area is on average $117.9 \mathrm{~km}$ per day (range $88.4-193.0 \mathrm{~km}$ per day). This is quite high compared to the speed of movement within the presumed moulting area (17.5, range $10.8-23.0 \mathrm{~km}$ per day) and even likely to be considerably underestimated as the detailed movements of the birds are not represented in the modelled paths due to the large errors and the low time resolution in the raw position data. Thus, flying was probably primary in moving the distance from the presumed moulting area to the wintering area. However, both the speed of movement and the daily proportion of dry recordings from the salt water immersion sensor, which never exceeds 0.5 , suggest that quite a bit of time was spent on the water, resting between legs of flight, feeding or swimming/drifting on the southwards current towards the wintering area. All birds tracked in 2007 spent the winter in pelagic waters far east of the Newfoundland coast (Fig. 2). In contrast, the bird tracked in 2008 remained off Iceland from late October to February when the logger stopped recording prematurely (Fig. 2).

Determining the spatial distribution is essential for understanding and forecasting future impacts of environmental 
change and anthropogenic activities on marine species. Although our sample size is small, our study provides important new insights into the poorly known ecology of one of the most abundant seabird species worldwide. Most notably, we identified for the first time a post-breeding staging area for little auks during their moulting period. Little auks are flightless during their moult (Gaston and Jones 1998) and therefore may be more vulnerable to any sudden degradation of their environment such as an oil spill or a local decrease in food availability. Further study is now needed to confirm our results and to determine the importance of this specific area. In particular, it is important to better delineate its maximum extent, estimate the number of birds moulting here, what they are feeding at and investigate whether little auks from other colonies in east Greenland or Svalbard use it on an annual basis.

Acknowledgments We thank David Grémillet, Ewan Weston, Rachael Orben, Luis de Sousa and Régis Cavignaux for their hard work in the field. We are grateful to James W. Fox and Janet R. D. Silk (British Antarctic Survey) for valuable advice in data download and processing and Martin Munck and NANUTravel for their logistical support. This study was funded by Bureau of Minerals and Petroleum, Greenland Government, as part of the KANUMAS Programme and by the French Polar Institute Paul Emile Victor (Grant 388 to David Grémillet) and the National Science Foundation (grant 0612504 to A.H. and Nina Karnovsky). Fieldwork was conducted under permits of the ethics committee of the French Polar Institute (MP/03/12/04/10) and with the permission from the Greenland Home Rule Government $\left(n^{\circ} 66.01 .13\right)$. This study represents a contribution to the British Antarctic Survey Ecosystems Programme.

\section{References}

Barrett RT, Chapdelaine G, Anker-Nilssen T, Mosbech A, Montevecchi WA, Reid JB, Veit RR (2006) Seabird numbers and prey consumption in the North Atlantic. ICES J Mar Sci 63:1145-1158

Beaugrand G, Edwards M, Legendre L (2010) Marine biodiversity, ecosystem functioning, and carbon cycles. Proc Natl Acad Sci USA 107:10120-10124

Birkhead TR, Taylor AM (1977) Moult of the Guillemot Uria aalge. Ibis 119:80-85

Boertmann D, Mosbech A, Schiedek D, Johansen KL (2009) The eastern Baffin Bay: a preliminary strategic environmental impact assessment of hydrocarbon activities in the KANUMAS West area, National Environmental Research Institute, Aarhus University. NERI Technical Report, p 720. http://www.dmu.dk

Boertmann D, Mosbech A, Schiedek D, Johansen KL (2009) The western Greenland Sea: a preliminary strategic environmental impact assessment of hydrocarbon activities in the KANUMAS East area, National Environmental Research Institute, Aarhus University. NERI Technical Report, p 719. http://www.dmu.dk

Buckland ST, Anderson DR, Burnham KP, Laake JL, Borchers DL, Thomas L (2001) Introduction to distance sampling. Estimating abundance of biological populations. Oxford University Press, Oxford

Egevang C, Stenhouse IJ, Phillips RA, Petersen A, Fox JW, Silk JRD (2010) Tracking of Arctic terns Sterna paradisaea reveals longest animal migration. Proc Natl Acad Sci USA 107:2078-2081
Fort J, Cherel Y, Harding AMA, Egevang C, Steen H, Kuntz G, Porter WP, Grémillet D (2010a) The feeding ecology of little auks raises questions about winter zooplankton stocks in North Atlantic surface waters. Biol Lett 6:682-684

Fort J, Cherel Y, Harding AMA, Welcker J, Jakubas D, Steen H, Karnovsky NJ, Grémillet D (2010b) Geographical and seasonal changes in isotopic niche of little auks. Mar Ecol Prog Ser 414:293-302

Fridolfsson AK, Ellegren H (1999) A simple and universal method for molecular sexing of non-ratite birds. J Avian Biol 30:116-121

Gaston AJ, Jones IL (1998) Bird families of the world: the auks. Oxford University press, Oxford

Guilford T, Meade J, Willis J, Phillips RA, Boyle D, Roberts S, Collett M, Freeman R, Perrins CM (2009) Migration and stopover in a small pelagic seabird, the Manx shearwater Puffinus puffinus: insights from machine learning. Proc R Soc B 276:1215-1223

Harding AMA, Egevang C, Walkusz W, Merkel F, Blanc S, Grémillet D (2009) Estimating prey capture rates of a planktivorous seabird, the little auk (Alle alle), using diet, diving behaviour, and energy consumption. Polar Biol 32:785-796

IPCC, Core Writing Team (2007) Climate change 2007: synthesis report. In: Pachauri RK, Reisinger A (eds) Contribution of working groups I, II and III to the fourth assessment. Report of the intergovernmental panel on climate change. IPCC, Geneva, Switzerland

Kampp K, Meltofte H, Mortensen CE (1987) Population size of the Little Auk Alle alle in East Greenland. Dan Ornithol Foren Tidsskr 81:129-136

Karnovsky NJ, Hunt GL (2002) Estimation of carbon flux to dovekies (Alle alle) in the North Water. Deep-Sea Res II 49:5117-5130

Karnovsky NJ, Harding AMA, Walkusz W, Kwaśniewski S, Goszczko I, Wiktor J Jr, Routti H, Bailey A, McFadden L, Brown Z, Beaugrand G, Grémillet D (2010) Foraging distributions of little auks Alle alle across the Greenland Sea: implications of present and future Arctic climate change. Mar Ecol Prog Ser 415:283-293

Kim YJ, Gu C (2004) Smoothing spline gaussian regression: more scalable computation via efficient approximation. J Roy Stat Soc B 66:337-356

Mehlum F, Gabrielsen GW (1995) Energy expenditure and food consumption by seabird populations in the Barents Sea region. In: Skjoldal HR et al (eds) Ecology of fjords and coastal waters. Elsevier, Amsterdam, pp 457-470

Phillips RA, Silk JRD, Croxall JP, Afabasyev V, Briggs DR (2004) Accuracy of geolocation estimates for flying seabirds. Mar Ecol Prog Ser 266:265-272

R Development Core Team (2009) R: a language and environment for statistical computing. Vienna: R foundation for Statistical Computing. ISBN 3-900051-07-0, http://www.R-project.org

Shaffer SA, Tremblay Y, Awkerman JA, Henry RW, Teo SLH, Anderson DJ, Croll DA, Block BA, Costa DP (2005) Comparison of light- and SST-based geolocation with satellite telemetry in freeranging albatrosses. Mar Biol 147:833-843

Stempniewicz L (2001) Alle alle Little Auk. J Birds Western Palearctic 3:175-201 (BWP Update, Oxford University Press, Oxford)

Tasker ML, Jones PH, Dixon TJ, Blake BF (1984) Counting seabirds at sea from ships: a review of methods employed and a suggestion for a standardized approach. Auk 101:567-577

Webb A, Durinck J (1992) Counting birds from ship. In Komdeur J, Berelsen J, Cracknell G (eds) Manual for aeroplane and ship surveys of waterfowl and seabirds. Slimbridge: International Wildfowl Research Bureau, pp 24-37

Wood SN (2006) Generalized additive models. An introduction with R. Chapman and Hall/CRC, Boca Raton

Wood SN (2008) Fast stable direct fitting and smoothness selection for generalized additive models. J R Stat Soc B 70:495-518 